\title{
8. REFERENCES
}

*ACGIH. 1994. Threshold limit values for chemical substances and physical agents and biological exposure indices (1994-1995). American Conference of Governmental Industrial Hygienists.

Cincinnati, $\mathrm{OH}$.

*ACGIH. 1996. Threshold limit values for chemical substances and physical agents and biological exposure indices. Second printing. American Conference of Governmental Industrial Hygienists. Cincinnati, $\mathrm{OH}$.

*Allied Chemical Corp. 1978. Properties, applications and handling of 4,4'-methylenedianiline. Material Safety Data Sheet.

*Andersen M, Binderup ML, Kiel P, et al. 1980. Mutagenic action of isocyanates used in the production of polyurethanes. Stand J Work Environ Health 6:221-226.

*Andersen ME, Clewell HJ, III, Gargas ML, et al. 1987. Physiologically based pharmacokinetics and the risk assessment process for methylene chloride. Toxicol Appl Pharmacol 87: 185-205.

*Andersen ME, Krishnan K. 1994. Relating in vitro to in vivo exposures with physiologically-based tissue dosimetry and tissue response models. In: Salem H, ed. Animal Test Alternatives. U.S. Army Chemical Research Development and Engineering Center, Aberdeen Proving Ground, Maryland.

*Anderson CC, Gunderson EC. 1986. Methods validation study of high performance liquid chromatographic technique for determining the MPDA and MDA content of air samples. Final Report. Govt Reports Announcements \& Index (GRA\&I), Issue 15.

*Anonymous. 1986. The health effects of aromatic amines-A review. King's College London, Monitoring and Assessment Research Centre, MARC, The Octagon Building, 459A Fulham Road, London SW10 OQX, United Kingdom, 127. Bibl.

*Atkinson R. 1985. Kinetics and mechanisms of the gas-phase reactions of the hydroxyl radical with organic compounds under atmospheric conditions. Chem Rev 85(1):69-201.

*Atkinson R, Carter WPL. 1984. Kinetics and mechanisms of the Gas-Phase Reactions of Ozone with Organic Compounds under Atmospheric Conditions. Chem Rev 84:437-470.

*ATSDR. 1989. Decision guide for identifying substance-specific data needs related to toxicological profiles. Agency for Toxic Substances and Disease Registry, Division of Toxicology, Atlanta, GA.

*ATSDR/CDC. 1990. Subcommittee report on biological indicators of organ damage. Agency for Toxic Substances and Disease Registry, Centers for Disease Control and Prevention, Atlanta, GA.

*Audunsson G, Mathiasson L. 1983. Simultaneous determination of amines and isocyanates in working atmospheres by gas-liquid chromatography. J Chromatogr 261:253-264.

*Cited in text 
*Avery MJ. 1989. Determination of aromatic amines in urine and serum. J Chromatogr Biomed Appl 488 (2):470-475.

*Bailey E, Brooks AG, Bird I, et al. 1990. Monitoring exposure to 4,4'-methylenedianiline by the gas chromatography-mass spectrometry determination of adducts to hemoglobin. Anal Biochem 190(2):175-181.

*Bailie MB, Hewett JA, Schultze AE et al. 1994. Methylene dianiline hepatotoxicity is not leukocyte-dependent. Toxicol Appl Pharmacol 124( 1):25-30.

*Bailie MB, Mullaney TP, Roth RA. 1993. Characterization of acute 4,4'-methylene dianiline hepatotoxicity in the rat. Environ Health Perspect 1Ol(2): 130-133.

*Barnes DG, Dourson M. 1988. Reference dose (RfD): Description and use in health risk assessments. U.S. Environmental Protection Agency. Regul Toxicol Pharmacol 8:471-486.

*Bastian PG. 1984. Occupational hepatitis caused by methylenedianiline. Med J Aust 141(8):533-555.

*Benfenati E, Natangelo M, Fanelli R, et al. 1992. Quantification of 4,4'-diaminodiphenylmethane by gas chromatography-negative-ion chemical-ionization mass spectrometry. Microchem J 46:352-359.

*Bidleman TF. 1988. Atmospheric Processes. Environ Sci Technol 22(4):361-367.

*Boeniger M. 1984. Industrial Hygiene Survey report of Olin Corporation, Moundsville, West Virginia. Dates of survey 30-31 August of 1983. Cincinnati, OH National Institute for Occupational Safety and Health, Centers for Disease Control, Industrial Hygiene Section, Industry-wide Studies Branch, Division of Surveillance, Hazard Evaluations and Field Studies.

*Bourdelat D, Moulinox JP, Chambon Y, et al. 1983. Intrahepatic biliary ductular proliferation in the pregnant rat treated with 4,4-diaminodiphenylmethane (4,4-DDPM). Bull Assoc Anat 67:375-382. [French].

*Brooks LJ, Neale JM, Pieroni DR. 1979. Acute myocardiopathy following tripathway exposure to methylenedianiline. J Amer Med Assoc 242(14):1527-1528.

*Brunmark P, Dalene M, Skarping G. 1995. Gas chromatography negative ion chemical ionization mass spectrometry of hydrolyzed human urine and blood plasma for the biomonitoring of occupational exposure to 4,4 methylenebisaniline. Department of Occupational and Environmental Medicine, University Hospital S-221 85 Lund, Sweden.

*Brunmark P, Persson P, Skarping G. 1992. Determination of 4,4'-methylenedianiline m hydrolyzed human urine by micro liquid chromatography with ultraviolet detection. J Chromatogr 579 (2):350-354.

*Bysshe SE. 1990. Bioconcentration factor in aquatic organisms. In: Lyman WJ, Rheehl WF, Rosenblatt DH, eds. Handbook of Chemical Property Estimation Methods. American Chemical Society, Washington DC, 5-5. 
*Clewell HJ III, Andersen M. 1985. Risk Assessment extrapolations using physiologically-based pharmacokinetic modeling. Toxicol Ind Health 1: 111- 131 .

*CMA. 1982. Summary of information on 4,4,-methylenedianiline collected by a survey of the chemical manufacturers associations's methylenedianiline program with cover letter dated 11-04-82. EPA OTS Dot. \# 40-8261190.

*Cocker J, Boobis AR, Davies DS. 1986b. Routes of activation of 4 4'-methylenebis-2-chloroaniline And 4 4'-methylenedianiline to bacterial mutagens. Food Chem Toxicol 24(6-7):755-756.

*Cocker J, Brown LC, Wilson HK, et al. 1988. GC-MS method for the determination of 4,4'-diaminodiphenylmethane (4,4'-methylenedianiline) and substituted analogues in urine. J Anal Toxicol 12:9-14.

*Cocker J, Gristwood W, Wilson HK. 1986a. Assessment of occupational exposure to 4,4' diaminodiphenylmethane (methylene dianiline) by gas chromatography-mass spectrometry analysis of urine. Br J Ind Med 43 (9):620-625.

*Cocker J, Nutley BP, Wilson H K. 1994. A biological monitoring assessment of exposure to methylene dianiline in manufacturers and users. Occup Environ Med 51:5 19-522.

*Concialini V, Chiavari G, Vitali P. 1983. Electrochemical detection in high performance liquid chromatographic analysis of aromatic amines. J Chromatogr 258( 1-2):244-25 1.

*Cragle DL, Wells SM, Tankersley G. 1992. An occupational morbidity study of a population potentially exposed to epoxy resins, hardeners, and solvents. Appl Occup Environ Hyg 7(12):826-834.

*Dalene M, Skarping G, Brunmark P. 1995. Assessment of occupational exposure to 4,4,'-methylene dianiline by the analysis of urine and blood samples. Int Arch Occup Environ Health 67:67-72.

*Deichmamr WB, Macdonald WE, Coplan M, et al. 1978. Di-(4-aminophenyl)-methane (MDA)4-7-year dog feeding study. Toxicology 1 1(2):185-1 88.

*DuPont. 1975. Ten-day subacute exposure of rabbit to methylene dianiline. Dot ID. 878220288. (Unpublished study)

*DuPont. 1976a. Skin absorption studies in rabbits treated with 4,4'-diaminodiphenylmethane (MDA). A. pathological and clinical effects of a lo-day subacute study. Dot ID. 878220289. (Unpublished study)

*DuPont. 1976b. Eye toxicity of aniline, 4,4'-methylenedianiline (MDA). Dot ID: 878220284. (Unpublished study)

*Eisenreich SJ, Looney BB, Thornton JD. 1981. Airborne organic contaminants in the Great Lakes Ecosystem. Environ Sci Technol 15:30-38.

*El-Hawari M, Stoltz M, Czarnecki D, et al. 1986. Dermal absorption of (14)C-labeled 4,4' methylenedianiline $\left(4,4^{\prime}\right.$-MDA) in rats, guinea pigs, and monkeys. Govt Reports Announcements \& Index (GRA\&I), Issue 13. 
*Emmett EA. 1976. Allergic contact dermatitis in polyurethane plastic molders. J Occup Med 18 (12):802-804.

*Endo Y, Hara I. 1991. DNA-detection in rats administered with 4,4'-methylenedianiline or 4,4'-methylenebis (2-chloroaniline). Sangyo Igaku 33:430-431. [Japanese].

*EPA. 1981. Standards of performance for equipment leaks of VOC in the synthetic organic chemicals manufacturing industry. List of chemicals produced by affected facilities. U.S. Environmental Protection Agency. Code of Federal Regulations. 40 CFR 60.489.

*EPA. 1987. Toxic chemical release reporting: Community right-to-know. Chemicals and chemical categories to with this part applies. U.S. Environmental Protection Agency. Code of Federal Regulations. 40 CFR 372.65

*EPA. 1990. Interim methods for development of inhalation reference doses. U.S. Environmental Protection Agency. EPA-600/8-90/066A.

*EPA. 1992. Effluent guidelines and standards. Organic chemicals, plastics and synthetic fibers. Applicability; description of the bulk organic chemicals subcategory. U.S. Environmental Protection Agency. Code of Federal Regulations. 40 CFR 414.70.

*EPA. 1994. National emission standards for hazardous air pollutants (NESHAPS) from source categories. Organic hazardous air pollutants from SOCMI. U.S. Environmental Protection Agency. Code of Federal Regulations. 40 CFR 63.106.

*EPA. 1995a. ASTER Ecotoxicity Profile on 4,4,'-Methylenedianiline. U.S. Environmental Protection Agency, Environmental Research Laboratory, Duluth, MN.

*EPA. 1995b. National emissions standards for wood furniture manufacturing operations. Tables 2, 4, and 6. U.S. Environmental Protection Agency. Code of Federal Regulations. 40 CFR 63, Subpart JJ.

*EPA. 1995c\%. Designation, reportable quantities, and notification. List of hazardous substances and reportable quantities. U.S. Environmental Protection Agency. Code of Federal Regulations. 40 CFR 302.4

*EPA. 1996. Interim status standards for owners and operators of hazardous waste treatment, storage, and disposal facilities. Compounds with Henry's law constant less than 0.1. U.S. Environmental Protection Agency. Code of Federal Regulations. 40 CFR 265, Appendix VI.

*Ernes DA, Hanshumaker DT. 1983. Determination of extractable methylenebis(aniline) in polyurethane films by liquid chromatography. Anal Chem 55:408-409.

*Farmer PB, Bailey E. 1989. Protein-carcinogen adducts in human dosimetry. Arch Toxicol Suppl 13:83-90.

*Farmer PB, Bailey E, Naylor S, et al. 1993. Identification of endogenous electrophiles by means of mass spectrometric determination of protein and DNA adducts. Symposium on Biomarkers in Human 
Cancer, Part II: Exposure monitoring and molecular dosimetry, Kailua-Kona, Hawaii, U.S.A., October 26-November I, 1991. Environ Health Perspect 99: 19-24.

*FDA. 1977a. Indirect food additives: Adhesives and components of coatings. Substances for use as components of coatings-resinous and polymeric coatings. U.S. Food and Drug Administration. 21 CFR 175.300

*FDA. 1977b. Indirect food additives: Polymer. Substances for use as basic components of single and repeated use food contact surface-polyurethane resins U.S. Food and Drug Administration. 21 CFR 177.1680

*FDA. 1977 . Indirect food additives: Polymer. Substances for use as basic components of articles intended for repeated use-4,4-isopropylidenedphenolepichlorohydrin thermosetting epoxy resins. U.S. Food and Drug Administration. 21 CFR 177. 2280

*FEDRIP. 1997. Federal Research in Progress: Methylene dianiline. Dialog Information Service, Inc.

*Foureman P, Mason JM, Valencia R, et al. 1994. Chemical mutagenesis testing in Drosophila: X. Results of 70 coded chemicals tested for the National Toxicology Program. Environ Molecular Mutagenesis 23(3):208-227.

*Fukushima S, Hirose M, Hagiwara A, et al. 1981. Inhibitory effect of 4,4'-diaminodiphenylmethane on liver, kidney and bladder carcinogenesis in rats ingesting N-ethyl-N-hydroxyethylnitrosamine or N-butyl-N-(4-hydroxybutyl) nitrosamine. Carcinogenesis 2(10): 1033-1037.

*Fukushima S, Shibata M, Hibino T, et al 1979. Intrahepatic bile duct proliferation induced by 4,4-diaminodiphenylmethane in rats. Toxicol Appl Pharmacol 48: 145-155.

*Griswold Jr. DP, Casey AE, Weisburger EK, et al. 1968. The carcinogenicity of multiple intragastric doses of aromatic and heterocyclic nitro or amino derivatives in young female SpragueDawley rats. Cancer Research 28:924-933.

*Gunderson EC, Anderson CC. 1988. A sampling and analytical method for airborne m-phenylenediamine (MPDA) and 4,4'-methylenedianiline (MDA). Am Ind Hyg Assoc J 49 (10):531-538.

*Hagiwara A, Tiwawech D, Imaida K, et al. 1993. Modifying influence of prior treatment with toxic agents on induction of preneoplastic and neoplastic lesions in a medium-term multi-organ carcinogenesis bioassay. Teratogenesis Carcinog Mutagen 13(6):277-287.

*Hall AJ, Harrington JM, Waterhouse JA. 1992. The Epping jaundice outbreak: A 24-year follow up. J Epidemiol Community Health 46(4):327-328.

*Harris JC. 1990. Rate of hydrolysis. In: Lyman WJ, Rheehl WF, Rosenblatt DH (eds). Handbook of Chemical Property estimation Methods. American Chemical Society, Washington, DC. 7-4.

*HazDat. 1997. Database. Agency for Toxic Substances and Disease Registry (ATSDR), Atlanta, GA. 
*Hewitt PG, Hotchkiss SAM, Caldwell J. 1995. Decontamination procedures after in vitro topical exposure of human and rat skin to 4,4'-methylenebis(2-chloroaniline) and 4,4'-methylenedianiline. Fund Appl Toxicol 26:91-98.

*Hiasa Y, Kitahori Y, Enoki N, et al. 1984. 4,4'-Diaminodiphenylmethane: promoting effect on the development of thyroid tumors in rats treated with N-bis(2-hydroxypropyl)nitrosamine. J Natl Cancer Inst 72(2):471-476.

*Ho T, Hardigree AA, Larimer FW, et al. 1979. Comparative mutagenicity study of potentially carcinogenic industrial compounds. Environ Mut 1: 167-1 68.

*Ho T, Tipton SC, Epler JL, et al. 1978. Cytogenetic effects of M-phenylene diamine (MPDA) and methylene dianiline (MDA) on human leukocytes in vitro. In vitro 14(4):350.

*Holland JM, Smith LH, Frome E, ET AL. 1987. Test of Carcinogenicity in Mouse Skin:

Methylenedianiline, gamma Glycidyloxytrimethyloxysilane, gamma Aminopropyltriethoxysilane and a mixture of M-phenylenediamine, methylenedianiline, and diglycidylether of Bisphenol-A. Govt Reports Announcements \& Index (GRA\&I), Issue 23.

*Hotchkiss SAM, Hewitt P, Caldwell J. 1993. Percutaneous absorption of 4,4'-methylenebis-( 2-chloroaniline) and 4,4,'-methylene dianiline through rat and human skin in vitro. Toxicol

In vitro 7(2): 141-148.

*Howard PH, Boethling RS, Jarvis WF, et al, eds. 1991. Handbook of Environmental Degradation Rates. Lewis Publishers, Inc., Chelsea, MI, 354-355.

*HSDB. 1996. Hazardous Substance Data Bank. National library of medicine. National Toxicology Program, Bethesda, MD.

*IARC. 1986. IARC monographs on the evaluation of carcinogenic risk of chemicals to humans: Vol 39. World Health Organization, Lyon, France. 347-365.

*IARC. 1987. IARC monographs on the evaluation of carcinogenic risks to humans. Supplement 7 , Overall evaluation of carcinogenicity: an updating of IARC monographs (Volumes 1 to 42).

International Agency for Research on Cancer. Lyon, France.

*III (International Isocyanate Institute). 1980. Biodegradation of toluene diisocyanate and diphenyl methane diisocyanate. EPA OTS Dot. \#86-870000646.

*III (International Isocyanate Institute). 1981. Bioaccumulation and toxicity of isocyanates and their water reaction products in fish with attachments and cover letter. Submitted to the Office of Toxic Substances. EPA. OTS Dot. \#86-870000616.

*III (International Isocyanate Institute). 1986. Biological decomposition of MDA (TDA and MDA biodegradability) with cover letter dated 01-17-88. EPA. OTS Dot. \#86-870000084.

*III (International Isocyanate Institute). 1987. Analysis of products in the biodegradation process of MDA and TDA (final report) with cover letter dated 03-1 1-88. EPA OTS Dot. \#86-870000166. 
*IRIS. 1995. Integrated Risk Information System (IRIS) office of health and environmental assessment, environmental criteria and assessment office. Cincinnati, $\mathrm{OH}$.

*Kajbaf M, Sepai 0, Lamb JH, et al. 1992. Identification of metabolites of 4,4-diaminodiphenylmethane (methylene dianiline) using liquid chromatographic and mass spectrometric techniques. $\mathrm{J}$ Chromatogr 583(1):63-76.

*Kanz MF, Kaphalia L, Kaphalia BS, et al. 1992. Methylene dianiline: acute toxicity and effects on biliary function. Toxicol Appl Pharmacol 117(1):88-97.

*Kanz MF, Wang A, Campbell GA. 1995. Infusion of bile from methylene dianiline-treated rats into the common bile duct injures biliary epithelial cells of recipient rats. Toxicol Letters 78:165171.

*Kopelman H. 1968. The Epping Jaundice after two years. Postgraduate Med J 44:78-80.

*Kopelman H, Robertson MH, Sanders PG, et al. 1966. The Epping Jaundice. Brit Med J 1:514-516.

*Kopelman K, Andersen ME. 1994. Physiologically-based pharmacokinetic modeling in toxicology. In: Wallace Hayes, ed. Principles and Methods of Toxicology. 3rd edition. Raven Press, Ltd. New York, NY.

*Krishnan K, Andersen ME, Clewell HJ III, et al. 1994. Physiologically-based pharmacokinetic modeling of chemical mixtures. In: Yang RSA, ed. Toxicology of Chemical Mixtures. Academic Press, New York, NY.

*Lamb JC, Huff JE, Haseman JK, et al. 1986. Carcinogenesis studies of 4,4'-methylenedianiline dihydrochloride given in drinking water to $\mathrm{F} 344 / \mathrm{N}$ rats and $\mathrm{B} 6 \mathrm{C} 3 \mathrm{~F}$, mice. J Toxicol Environ Health 18(3):325-337.

*LaVoi E, Tulley L, Fow E, et al. 1979. Mutagenicity of amionphenyl and nitrophenyl ethers, sulfides and disulfides. Mutat Res 67: 123-131.

*Leong BK, Lund JE, Groehn JA, et al. 1987. Retinopathy from inhaling 4,4'-methylenedianiline aerosols. Fund Appl Toxicol 9(4):645-658.

*Leung H. 1993. Physiologically-based pharmacokinetic modeling. In: Ballantine B, Marro T, Turner T. eds. General and Applied toxicology. Stockton Press. Vol 1, 153-164.

*Levine MJ. 1983. Occupational photosensitivity to diaminodiphenylmethane. Contact Dermatitis 9 (6):488-490.

*Lewis RJ, Sr.(ed). 1993. Hawley's Chemical Dictionary. 12th. ed, Van Nostrand Reinhold Co., New York, NY. 362.

*Lide DR. (ed). 1994. CRC Handbook of Chemistry and Physics, 75th ed. CRC Press, Boca Raton FL. 3-24. 
*Liss GM, Guirguis SS. 1994. Follow-up of a group of workers intoxicated with 4,4'-methylenedianiline. Amer J Ind Med 26: 117-124.

*Lyman WJ, Reehl WF, Rosenblatt DH, et al. 1990. Handbook of Chemical Property Estimation Methods. American Chemical Society, Washington, DC.

*Masui T, Tsuda H, Inoue K, et al. 1986. Inhibitory effects of ethoxyquin, 4,4'-diaminodiphenylmethane and acetaminophen on rat hepatocarcinogenesis. Jpn J Cancer Res 77(3):231-237.

*Mathiasson L, Jonsson JA, Karlsson L. 1989. Determination of nitrogen compounds by supercritical-fluid chromatography using nitrous oxide as the mobile phase and nitrogen-sensitive detection. J Chromatogr 467:61-74.

*Mazzu AL, Smith CP. 1984. Determination of extractable methylene dianiline in thermoplastic polyurethanes by HPLC. J Biomed Mater Res 18(8):961-968.

*McCarthy DJ, Struck RF, Shih TW, et al. 1982. Disposition and metabolism of the carcinogen reduced Michler's ketone in rats. Cancer Res 42(9):3475-3479.

*McGill DB, Motto JD. 1974. An industrial outbreak of toxic hepatitis due to methylene dianiline. New England J Med 291: 278-282.

*Mcgregor D B, Brown A, Cattanach P, et al. 1988. Responses of the L5178Y Tk-positivetknegative Mouse Lymphoma Cell Forward Mutation Assay III. 72 coded chemicals. Environ Mol Mutagen 12(1):85-154.

*Merck Index. 1989. Merck index: an encyclopedia of chemicals, drugs, and biologicals. 1 lth ed. Budavari S, ed. Rahway NJ: Merck \& Co., Inc.

*Messerly EA, Fekete JE, Wade DR, et al. 1987. Structure mutagenicity relationships of benzidine analogues. Environ Mol Mutag 10: 263-274.

*Mirsalis J, Tyson K, Beck J, et al. 1983. Induction of unscheduled DNA synthesis (UDS) in hepatocytes following in vitro and in vivo treatment. Environ Mutagen 5:482.

*Miyamoto J, Okuno Y, Kadota T, et al. 1977. Experimental hepatic lesions and drug metabolizing enzymes in rats. J Pestic Sci (Nihon Noyakugaku Kaishi); 2(3):257-270.

*Moore WM. 1978. Methylenedianiline. Kirk-Othmer Encyclopedia of Chemical Technology, 3rd ed., Vol. 2, New York John Wiley \& Sons 338-348.

*Mori H, Yoshimi N, Sugie S, et al. 1988. Genotoxicity of epoxy resin hardeners in tie hepatocyte primary culture-DNA repair test. Mutat Res 204 (4):683-688.

*NAS/NRC. 1989. Biologic markers in reproductive toxicology. National Academy of Sciences/ National Research Council. Washington, DC: National Academy Press, 15-35. 
*NATICH. 1992. NATICH data base report of federal, state, and local air toxics activities. Research Triangle Park, NC: U.S. Environmental Protection Agency, Office of Air Quality Planning and Standards, National Air Toxics Information Clearinghouse. EPA-453\R-92-008.

*NCI. 1985. Monograph on human exposure to chemicals in the workplace. National Cancer Institute Bethesda, MD.

*NFPA. 1994. Fire Protection Guide and Handbook.

*NIEHS. 1994. Seventh annual report on Carcinogens 1994 Summary. 4,4'-Methylenedianiline and its dihydrochloride. U.S. Department of health and Human Services, Public Health Service, National Institute of Environmental Health Sciences, Research Triangle Park, NC. 250-253.

*NIOSH. 1976. Current Intelligence Bulletin 8. 4,4-Diaminodiphenylmethane (DDM) (with reference package). Current Intelligence Bulletin 8, NIOSH, U.S. Department of Health, Education, and Welfare, Cincinnati.

*NIOSH. 1986. Current Intelligence Bulletin 42. 4,4,' Methylenedianiline (MDA). U.S. Department of Health and Human Services, Public Health Services, Centers for Disease Control and Prevention, National Institute for Occupational Safety and Health. DHHS (NIOSH) Publications No. 86-115.

*NIOSH. 1989. National Occupational Exposure Survey. Cincinnati, OH: U.S. Department of Health and Human Services, Public Health Services, Center for Disease Control, National Institute of Occupational Safety and Health.

*NIOSH. 1991. NIOSH Manual of Analytical Methods (third Edition). Fourth Supplement. Govt Reports Announcements \& Index (GRA\&I), Issue 10.

*NIOSH. 1992. Recommendations for occupational safety and health. Compendium of policy documents and statements. U.S. Department of Health and Human Services, National Institute of Occupational Safety and Health, Cincinnati, $\mathrm{OH}$.

*NIOSH. 1994. Manual of Analytical Methods. 4th edition. National Institute for Occupational Safety and Health, Centers for Disease Control and Prevention, Public Health Service, U. S. Department of Health and Human Services.

*NIOSH. 1997. NIOSH pocket guide to chemical hazards. National Institute for Occupational Safety and Health, Cincinnati, $\mathrm{OH}$.

*NOES. 1989. National Occupational Exposure Survey (1981-1983): Methylene dianiline. Cincinnati, OH: U.S. Department of Health and Human Services, National Institute for-Occupational Safety and Health.

*Norwitz G, Keliher PN. 1986. Continued investigation of the diazotization and coupling spectrophotometric technique for the determination of aromatic amines with 8-amino-1 -hydroxy-3, 6-naphthalenedisulfonic acid and n-1 naphthylethylenediamine AS coupling agents. Talanta 33

(4):311-314.

*NRC. 1989. National Research Council. Washington, DC: National Academy Press. 
*NTDB. 1994. The National Trade Data Bank. Washington, DC: U.S. Department of Commerce, Economics and Statistics Administration (CD-ROM).

*NTP. National Toxicology Program. 1983. Carcinogenesis studies of 4,4'-methylenedianiline dihydrochloride in F344/N rats and B6C3F, mice (drinking water studies). U.S. Department of Health and Human Services. Technical Report No. 248.

*OSHA. 1974. Air contaminants. Occupational Safety and Health Administration. Code of Federal Regulations. 29 CFR 1910.1050.

*OSHA. 1992a. Occupational Safety and Health Standards. Methylenedianiline. U.S. Occupational Safety and Health Administration. 29 CFR 1910.1050.

*OSHA. 1992b. Safety and health regulations for construction. Occupational health and environmental controls. Methylenedianiline. U.S. Occupational Safety and Health Administration. 29 CFR 1926.50.

*OTA. 1990. Neurotoxicology: Identifying and controlling poisons of the nervous system. Office of Technology Assessment, Washington, DC. OTA-BA-438.

*Parodi S, Taningher M, Russo P, et al. 1981. DNA-damaging activity in vivo and bacterial mutagenicity of 16 aromatic amines and azo derivatives, as related quantitatively to their carcinogenicity. Carcinogenesis (LOND); 2( 12): 1317-1326.

*Parodi S, Zunino A, Ottaggio L, et al. 1983. Lack of correlation between the capability of inducing sister-chromatid exchanges in vivo and carcinogenic potency for 16 aromatic amines and azo derivatives. Mutat Res 108(1-3):225-238.

*Parr-is GE. 1980. Covalent binding of aromatic amines to humates. I. Reactions with carbonyls and quinones. Environ Sci Technol 14: 1099-1 106.

*Peterson JC, Estiva EC, Lyttle DS, et al. 1991. High-performance liquid chromatographic determination of 4,4,-methylene dianiline in human urine. J Chromatogr 564(1):205-212.

*Pludro G, Karlowski K, Mankowska M, et al. 1969. Toxicological and chemical studies of some epoxy resins and hardeners. I. Determination of acute and subacute toxicity of phthalic acid anhydride, 4,4'-diaminophenylmethane and of the epoxy resin: epilox EG-34. Acta Pol Pharm 26:352-357.

*Rannug A, Ram-rug U, Ramel C. 1984. Genotoxic effects of additives in synthetic elastomers with special consideration to the mechanism of action of thiurames and dithiocarbamates, in: industrial - hazards of plastics and synthetic elastomers. Prog Clin Biol Res 141:407-419.

*Rae TK, Dorsey GF, Allen BE, et al. 1982. Mutagenicity of 4,4'-methylenedianiline derivatives in the Salmoneh histidine reversion assay. Arch Toxicol 49 (3-4):185-190.

*Robert A, Ducos P, Francin JM. 1995. Determination of urinary 4,4'-methylenedianiline and its acetylated metabolites by solid-phase extraction and HPLC analysis with UV and electrochemical detection. Int Arch Occup Environ Health 68:44-51. 
*Rouchaud J, Gustin F, Benoit F, et al. 1992. Isocyanates and their metabolites in nutrient solutions and fruit and leaf vegetables in soilless crops on rebounded polyurethane substrates.

Gartenbauwissenschaft. 57(5):243-245.

*Roy CW, McSorley PD, Syme IG. 1985. Methylene dianiline: a new toxic cause of visual failure with hepatitis. Hum Toxicol 4(1):61-66.

*RTECS. 1996. Registry of Toxic Effects of Chemical Substances (RTECS). National Institute for Occupational Safety and Health (NIOSH). Computer database online.

*Sadtler. 1974. Ultraviolet spectra (No. 18317). Sadtler Research Laboratories, Inc., Philadelphia, PA.

*Schmidt P, Burck D, Weigmann HJ. 1974. On the acute toxicity of amines important for the plastics industry. Journal for Comprehensive Hygiene and Related Fields 20:393-398. [German].

*Schmidt P, Gohlke R, Just A, et al. 1980. Combined action of hepatotoxic substances and increased environmental temperature on the liver of rats. J Hyg Epidemiol Microbial Immunol 24 (3):271-276.

*Schiitze D, Sagelsdorff P, Sepai 0, et al. 1996. Synthesis and quantification of DNA adducts of 4,4,'-methylenedianiline. Chem Res Toxicol 9:1103-1 112.

*Schiitze D, Sepai 0, Lewalter J, et al. 1995. Biomonitoring of workers exposed to 4,4 methylenedianiline or 4,4 methylenediphenyl diisocyanate. Carcinogenesis 16:573-582.

*Selden A, Berg P, Jakobsson R, et al. 1992. Methylene dianiline: Assessment of exposure and cancer morbidity in power generator workers. Int Arch Occup Environ Health 63(6):403-408.

*Sepai 0, Henschuler D, Sabbioni G. 1995. Albumin adducts, hemoglobin adducts and urinary metabolites in workers exposed to 4,4'-methylenediphenyl diisocyanate. Carcinogenesis 16(10):2583-2587.

*Shimizu H, Takemura N. 1976. Mutagenicity of Some Amino Compounds and its Relation to Carcinogenicity. Jap Ind Health (Sangyo Igaku), 18(2): 138-139.

*Shintani H. 1991. Solid-phase extraction of a carcinogen, 4,4'-methylenedianiline, in serum. J Anal Toxicol 15(4):198-201.

*Shintani H. 1992. Solid-phase extraction (SPE) and HPLC analysis of toxic compounds and comparison of SPE and liquid-liquid extraction: I. Analysis of 4,4'- methylenedianiline in serum: II. Analysis of the components of dental materials. J Liq Chromatogr 15(8): 1315-1335.

*Shintani H. 1995a. Formation and elution of toxic compounds from sterilized medical products: Methylene dianiline formation in polyurethane. J Biomater Appl 10:23-58.

*Shintani H. 1995b. The relative safety of gamma-ray, autoclave, and ethylene oxide gas sterilization of thermosetting polyurethane. Biomedical Instrumentation and Technology 29:513-519. 
*Shuker LK, Batt S, Rystedt I, et al. 1986. The health effects of aromatic amines a review. Monitoring and Assessment Centre King's College London, Univ of London, on behalf of International Programme on Chemical safety (UNEP/ILO/WHO), with support of United Nations Environment Programme.

*Skarping G, Dalene M. 1995. Determination of 4,4'-methylenediphenyldianiline (MDA) and identification of isomers in technical-grade MDA in hydrolyzed plasma an urine from workers exposed to methylene diphenyldiisocyanate by gas chromatography-mass spectrometry. J Chromatogr B, 663:209-2 16.

*Skarping GL, Renman L, Darlene M. 1983. Trace analysis of amines and isocyanates using glass capillary gas chromatography and selective detection. II: Determination of aromatic amines as perfluorofatty acid amides using nitrogen selective detection. J Chromatogr 207:207-218.

*SRC. 1995. Database. Syracuse Research Corporation. Merrill Lane Syacuse, New York.

*SRI. 1994. Stanford Research Institute International. Directory of chemical producers: United States of America. Menlo Park, Ca: SRI International, 847.

*SRI. 1996. 1996 Directory of chemical producers: United States of America. Menlo Park, CA: Stanford Research Institute International.

*Steinhoff D, Grundmann E. 1970. On the carcinogenic effect of 4,4 diaminodiphenylmethane and 2,4 diaminodiphenylmethane. Naturwissenschaften 57:247-248. [German].

*Swarm RL, Laskowski DA, McCall PJ, et al. 1983. A rapid method for the estimation of the environmental parameters octanol/water partition coefficient, soil sorption constant, water to air ratio, and water solubility. Res Rev 85:17-28.

*Takemura N, Shimizu H. 1978. Mutagenicity of some aromatic amino and nitro compounds. Mutat Res 54(2):256-257.

*Tanaka K, Ino T, Sawahata T, et al. 1985. Mutagenicity of N-acetyl and N,N'-diacetyl derivatives of 3 aromatic amines used as epoxy-resin hardeners. Mutat Res 143(1-2): 11-15.

*Thomas RG. 1990a. Volatilization from water. In: Lyman WJ, Reehl WF, Rosenblatt DH, eds. Handbook of Chemical Property Estimation Methods. Washington, DC.: American Chemical Society, $15-11$.

*Thomas RG. 1990b. Volatilization from water. In: Lyman WJ, Reehl WF, Rosenblatt DH, eds. Handbook of Chemical Property Estimation Methods. Washington, DC.: American Chemical Society, $15-15$.

*Tiljander A, Skarping G. 1990a. Determination of 4,4'-methylenedianiline in hydrolyzed human urine using liquid chromatography with UV detection and peak identification by absorbance ratio. $\mathrm{J}$ Chromatogr 511:185-194. 
*Tiljander A, Skarping G, Dalene M. 1990b. Determination of 4,4'- methylenedianiline in hydrolyzed human urine as chloroformate derivative using column switching and liquid chromatography with UV detection. J Liq Chromatogr 13(4): 803-820.

*Tiljander AG, Skarping, Dalene M. 1989. Chromatographic determination of amines in biological fluids with special reference to the biological monitoring of isocyanates and amines. III.

determination of 4,4'-methylenedianiline in hydrolyzed human urine. J Chromatogr 479( 1): 145152.

*Tillmann HL, van, Pelt F, Martz W, et al. 1997. Accidental intoxication with methylene dianiline p,p'-diaminodiphenylmethane: Acute liver damage after presumed ecstasy consumption. Clinical Toxicology 35(1):35-40.

*Toeniskoetter RH. 1981. Urethane foundry binders-An industrial hygiene appraisal. NIOSH proceedings of the symposium of Occupational Health Hazard Control Technology in the Foundry and Secondary non-Ferrous Smelting Industries. U. S. Department of Health and Human Services, National Institute for Occupational Safety and Health.

*Tortoreto M, Catalani P, Bianchi M, et al. 1983. Determination of 4,4'-diaminodiphenylmethane in blood by gas-liquid chromatography with electron-capture detection. J Chromatogr 262:367-372.

*TRI94 1996. Toxic Release Inventory. Office of pollution Prevention U.S. Environmental Protection Agency, Washington, DC

*Tsuchiya Y. 1995. Chlorination byproducts of 4,4,'-methylene dianiline (MDA) and their mutagenicity. Wat Sci Tech 30(10): 153-259.

*Tsuda H, Ogiso T, Hasegawa R, et al. 1987. Inhibition of neoplastic development in rat liver, kidney, oesophagus and forestomach by $4,4^{\prime}$-diaminodiphenylmethane administration. Carcinogenesis 8(5):719-722.

*Tucker HL, Smith TK, Van Hook S J III. 1993. Determination of anions in an epoxy curing agent by ion chromatography. J Chromatogr 640(1-2):355-358.

*Tullner WW. 1960. Endocrine effects of methylene dianiline in the rat, rabbit and dog. Endocrinology 66:470-474.

*U.S. Congress. 1990. Clean air act amendments. Title III, Hazardous Air Pollutants, Section 112, Hazardous Air Pollutants as amended, October 26, 1990. One Hundred and First Congress of the United States of America, 2nd Session Report 101-952.

*USITC. 1991. Synthetic organic chemicals: United States production and sales, 1990. USITC Publication 2470. Washington, DC.: United States International Trade Commission.

*USITC. 1993. Synthetic organic chemicals: United States production and sales, 1992. USITC publication 2720. Washington, DC.: United States International Trade Commission.

*Van Joost T, Heule F, de Boer J. 1987. Sensitization to methylenedianiline and para-structures. Contact Dermatitis 16(5):246-248. 
*Vock EH, Hoymann H-G, Heimich U, et al. 1996. ${ }^{32}$ P-Postlabeling of a ${ }^{*}$ DNA adduct derived from 4,4, '-methylenedianiline, in the olfactory epithelium of rats exposed by inhalation to $4,4,{ }^{\text {' }}$ methylenediphenyl diisocyanate. Carcinogenesis 17(5): 1069- 1073.

*Williams SV, Bryan JA, Burk JR. 1974. Toxic hepatitis and methylenedianiline. New England J Med 291: 1256.

*Wu K, Leslie CL, Stacey NH. 1989. Effects of mutagenic and non-mutagenic aniline derivatives on rat liver drug-metabolizing enzymes. Xenobiotica 19(11): 1275-1283. 